\title{
Carbon dioxide evaporation process in direct expansion geothermal boreholes
}

\author{
Messaoud Badache \\ Zine Aidoun
}

\author{
Parham Eslami Nejad \\ Mohamed Ouzzane
}

\author{
Arash Bastani
}

\begin{abstract}
Ground Heat Exchangers (GHE) play an important role in the performance of Ground Source Heat Pumps (GSHP). The impact is even more significant in direct expansion GSHP (DX-GSHP) systems as the refrigerant used in the heat pump also acts as the beat transfer fluid for the GHE. In this study, several experiments were carried out to investigate the performance of GHEs in a carbon dioxide (CO $)$ DX-GSHP. The evaporation of $\mathrm{CO}_{2}$ in the GHE was studied under various mass flow rates and number of active boreholes. For this purpose, a transcritical CO $D X-G S H P$ test facility was built and fully equipped at CanmetENERGY-V arennes research laboratory. It was found that a partial two-phase flow regime along the GHE decreases the performance compared to the full two-phase flow and it has to be avoided for more efficient DX-GSHP systems.
\end{abstract}

\section{INTRODUCTION}

The global climate change and urge for using energy efficient systems call for the development and implementation of emerging eco-friendly technologies for heating and cooling applications. This new tendency has motivated the scientific community to adapt natural refrigerants such as carbon dioxide $\left(\mathrm{CO}_{2}\right)$ in DX-GSHP. The use of transcritical $\mathrm{CO}_{2}$ in DX-GSHP offers several opportunities for the cost reduction of the ground loop and makes these systems a promising environmentally friendly and energy efficient alternative compared to other heating equipment. In addition, CO2 is inexpensive to produce and has a relatively high vapour density as well as latent heat of evaporation. This and its working pressures allows for less refrigerant with small specific volume to be cycled than conventional refrigerants, achieving the same heating/cooling capacity and size reduction of the GHE as well as other system components.

One of the main components in transcritical $\mathrm{CO}_{2} \mathrm{DX}-\mathrm{GSHP}$ systems is the GHE, as it is the component where heat transfer between the GSHP system and the soil occurs. GHE heat transfer performance is the key factor influencing the operation performance of the entire system.

At present, a relatively few studies is reported on DX-GSHP. The available theoretical researches have mainly focused on numerical methods to simulate the GHE and study the effect of different parameters on the system performance (Ghazizade and Ameri, 2018; Yuefen, et al. 2017; Mastrullo 2014; Austin and Sumathy, 2011, Eslami Nejad, et al. 2014, and Eslami Nejad, et al. 2018). The modeling of transient behavior of GHE and the surrounding

Messaoud Badache (Messaoud.badache@canada.ca) is a research scientist at Natural Resources Canada. Parham Eslami Nejad, Arash bastani, and Zine Aidoun are research scientists at Natural Resources Canada. Mohamed Ouzzane is a professor in Mechanical Engineering Department, Islamic university in Madinah, Saudi Arabia: 
ground is somehow complex and only few transient models are available in the literature (Beauchamp, et al. 2013; Rousseau, et al. 2015; Eslami Nejad et al. 2015). Most of the experimental studies evaluated the whole system performance using typical refrigerants (Guo et al. 2012; Wang et al. 2009; Lenarduzzi and Bennet 1991 and Goulburn and Fearon 1978). Compared to other working refrigerants, $\mathrm{CO}_{2}$ has been the least studied. Several studies were performed to establish some guides and improvements for the design of such systems (Mei and Baxter, 1990 and Wang, et al. 2013) while others focused on various GHE types (i.e, horizontal, vertical, spiral or inclined) in the heating and cooling mode (Johnson, 2002; Minea, 2003 and Goulburn 1983). Recently Badache, et al., 2018 experimentally investigated the overall system performance, phase change of $\mathrm{CO}_{2}$ due to evaporation inside the ground heat exchanger and the effect of the number of boreholes on the system performance.

In the present work, several experiments were conducted to investigate the GHE performance using $\mathrm{CO}_{2}$ as the working fluid. For this purpose, a transcritical $\mathrm{CO}_{2}$ DX-GSHP test facility was built at CanmetENERGY-Varennes research laboratory. First, the profiles of the ground temperature and pressure drop through the boreholes are analysed. In the second step, the evaporation process taking place inside the heat exchanger and the related heat extraction performance were investigated for different number of active boreholes and the $\mathrm{CO}_{2}$ mass flow rate per borehole.

\section{DESCRIPTION OF THE EXPERIMENTAL SETUP AND TEST PROCEDURE}

\section{Experimental setup}

Figure 1(a) schematically shows the single-stage transcritical $\mathrm{CO}_{2}$ DX-GSHP test bench in heating mode. The main components of this test facility include a semi hermetic compressor (one ton nominal refrigeration capacity), the GHE, and a water loop for heat rejection from the gas cooler. An oil system consisting of a separator, a reservoir and a pressure regulating valve ensures adequate compressor lubrication while minimizes the amount of oil circulating in the whole cycle including the borehole. The test facility is fully equipped with different measuring devices including the pressure and temperature sensors and flowmeters. The system operates in three pressure levels namely high, intermediate, and low. The refrigerant $\left(\mathrm{CO}_{2}\right)$ is compressed to the high-pressure level (supercritical pressure) at point 2 with a corresponding temperature rise. Then, the high pressure-high temperature gas enters the gas cooler to heat water. After internal heat exchanger (IHE), $\mathrm{CO}_{2}$ is expanded to the intermiddiate-pressure level of the cycle (point 5). The two-phase $\mathrm{CO}_{2}$ enters the separator and the vapor portion is bypassed around the boreholes, while the liquid portion flows toward the boreholes. Then, $\mathrm{CO}_{2}$ with low vapor quality enters the boreholes, mixes with the the bypass vapor at the outlet of the boreholes, becomes superheated in IHE, and enters the compressor to complete the cycle. Note, for all tests, the pressure of the separator was set to 36.45 bars, corresponding to $1.7^{\circ} \mathrm{C}$.

The GHE consists of four 30-meter vertical boreholes with single cooper U-tube arranges in a square pattern with a uniform spacing of $6.25 \mathrm{~m}$. The boreholes dimensions and the grout filling material are listed in Table 1. Insitu thermal properties of the soil obtained from a thermal response test are given in Table 2. One of the boreholes was

equipped with temperature sensors in diferent levels to present the temperature profile of $\mathrm{CO}_{2}$ in both two legs of the U-pipe. Figure 1 (b) shows the location of those temperature sensors on the borehole. 
Table 1. Borehole dimensions

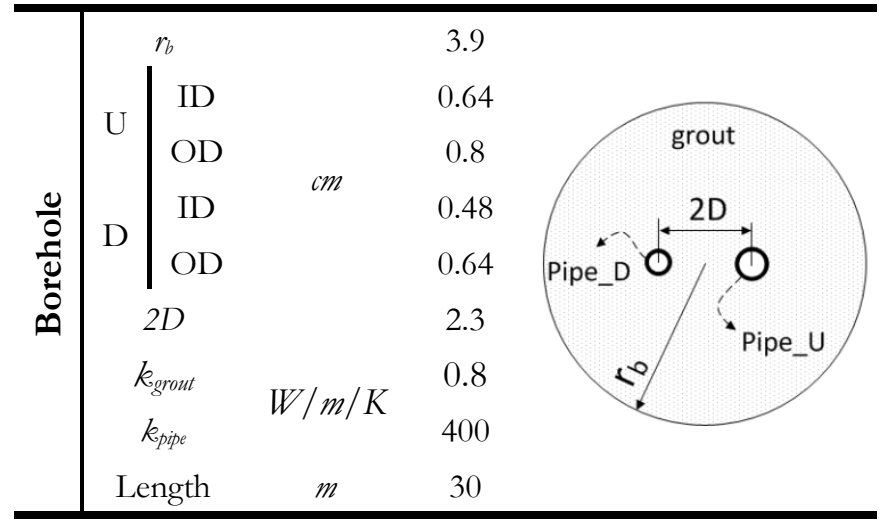

Table 2. Ground thermal properties

\begin{tabular}{|c|c|c|c|}
\hline \multirow{3}{*}{ 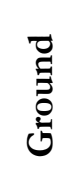 } & $K_{\text {ground }}$ & $W / m / K$ & 2.65 \\
\hline & $\left(\rho c_{p}\right)_{g}$ & $\mathrm{~kJ} / \mathrm{m}^{3} / \mathrm{K}$ & 2862 \\
\hline & UGT & ${ }^{\circ} \mathrm{C}$ & 9.5 \\
\hline
\end{tabular}

\section{Test procedure}

The system can be operated in two different modes; manual and automatic. The former is employed in the present work in which the opening position of the Expantion Valves (EVs) (installed before the inlet of the the boreholes) can be changed manually.

Each test started by adjusting the water temperature, the water mass flow rate, and the opening of the EVs. For each test, the same opening was fixed for all EVs involved. The temperature variation along the borehole is then recorded during the system operation. Note that the temperature measurements along the borehole were not taken directly on the $\mathrm{CO}_{2}$ but at the surface of both U-tube legs. Other data are also recorded from the test that enable the actual borehole extraction to be calculated and the actual pressure drop and enough information to yield any time dependent characteristics of the heat pump performance.

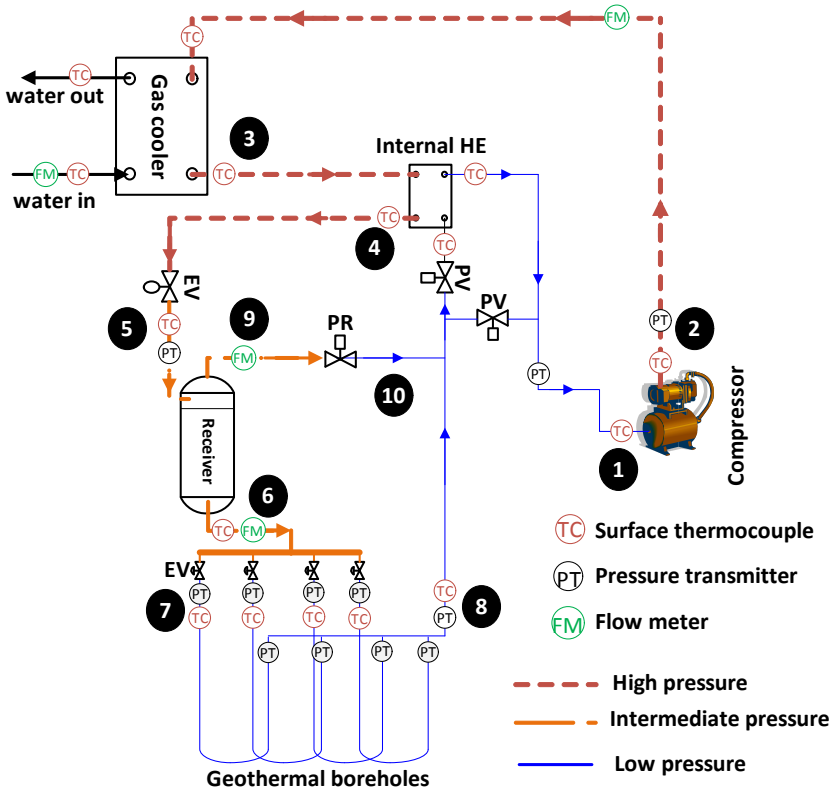

(a)

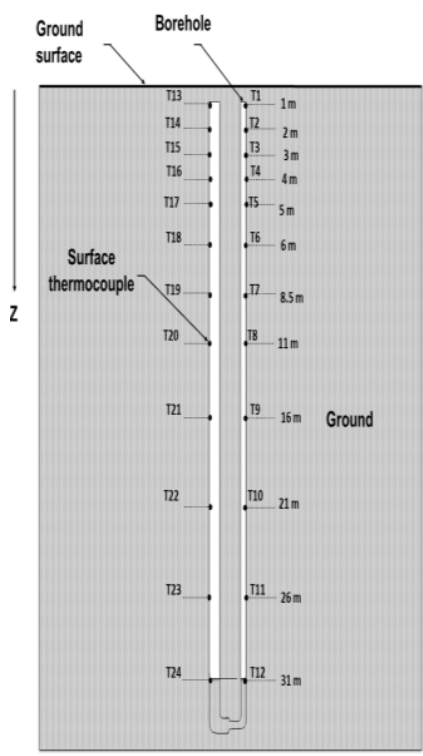

(b)

Figure 1. (a) Simplified schematic of the $\mathrm{CO}_{2}-\mathrm{DX}-\mathrm{GSHP}$ test facility; and (b) Position of the thermocouples in the GHE. 


\section{RESULTS AND DISCUSSION}

For investigating the GHE performance and the evaporation process taking place in the GHE, the profiles of the ground temperature and pressure drop through the boreholes are first analysed in this section.

\section{Ground temperature measurement}

The temperature distribution in the ground significantly affects the performance of the GHE. The profiles of the ground temperature for three days (April 20th, September 2nd, and October 24th) are presented in Figure 2. The profiles of the April 20 th and September $2^{\text {nd }}$ (black dash lines) present the ground temperature before conducting the first test (i.e. before operation of the $\mathrm{CO}_{2}$-DX-GSHP), thus they represent the far field ground temperature. For each profile, two different regions are observed; the shallow zone (up to 8 meters) and the deep zone (down to 31 meters). It can be seen that for the shallow zone, the ground temperature depends greatly on the seasonal weather conditions. In the deep zone, the ground temperature profile stays almost constant for both days, which corresponds to the undisturbed ground temperature (UGT). At the lower zone, the influence of the seasonal climate changes on the ground temperature is negligible. Note that the UGT values are in accordance with the value determined by the thermal response test, which is about $9.5^{\circ} \mathrm{C}$.

After running a number of tests, the ground temperature is expected to be disturbed as shown in the temperature profile of October 24th (blue dashed lines). It corresponds to the ground temperature in the vicinity of the borehole when the system was not operating. In fact, the actual ground temperature at the proximity of an active borehole is different than the far field temperature even at the time that the system is off. As can be seen in Figure 2, the deep zone temperature value is $1.5^{\circ} \mathrm{C}$ less than that measured on April $20^{\text {th }}$ and September $2^{\text {nd }}$.

An experimental estimates of soil temperature recovery after heat extraction test indicates that generally for the ground it took at least 8 hours for an adequate temperature recovery (i.e., to reach the profile in black). In consequence, a soil recovery time of 12 hours was scheduled before each test.

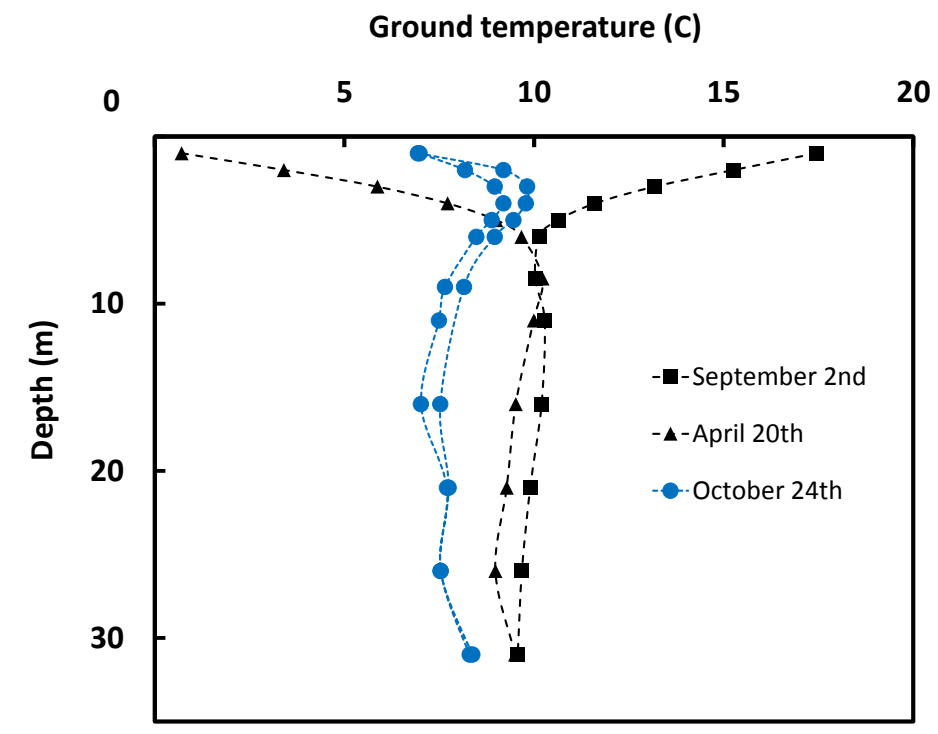

Figure 2. Measured ground temperature at different depths at Varennes for three days (April 20th, September 2nd, and October 24th). 


\section{Pressure drop through the boreholes}

Refrigerant pressure drop inside boreholes influences the performance of a GHE. Significant reduction in the pressure of the refrigerant results in an inconsistent evaporation temperature in a GHE. Therefore, to investigate the evaporation process inside a GHE, the pressure drop in a borehole needs to be measured. Thus, for different openings of the EVs $(40 \%, 20 \%$ and 10\%) the pressures at the inlet and the outlet of the boreholes were messured as presented in Figure 3. The tests were conducted with $\dot{m}_{\mathrm{w}}=0.27 \mathrm{~kg} / \mathrm{s}$ and $\mathrm{T}_{\mathrm{w}, \text { in }}=35^{\circ} \mathrm{C}$. It can be seen that when the opening of the EVs decreases from $40 \%$ to $10 \%$, the pressure in the borehole decreases. It is also observed that the pressure drop, $\Delta \mathrm{P}$ (difference between $\mathrm{CO}_{2}$ inlet and outlet pressure) along the boreholes is relatively small. Table 3 illustrates $\Delta \mathrm{P}$ values for different openings of the EVs. The maximum measured pressure drop was less than $80 \mathrm{kPa}$ (at $40 \%$ opening). In other openings of the EVs, the measured pressure drop is less than $40 \mathrm{kPa}$. The pressure drop has negligible effects on the evaporating pressure and therefore the evaporation temperature along the borehole remains almost constant.

Table 3. Pressure drop through the boreholes

\begin{tabular}{cccc}
\hline $\begin{array}{c}\text { Number } \\
\text { of } \\
\text { Boreholes }\end{array}$ & $\begin{array}{c}\text { EVs } \\
\text { Opening }\end{array}$ & $\begin{array}{c}\text { Pin } \\
(\mathbf{k P a})\end{array}$ & $\begin{array}{c}\Delta \mathbf{P} \\
\mathbf{( k P a )}\end{array}$ \\
\hline \hline 3 & $40 \%$ & 3422 & $\leq 80$ \\
3 & $20 \%$ & 3245 & $\leq 40$ \\
3 & $10 \%$ & 3116 & $\leq 40$ \\
\hline
\end{tabular}

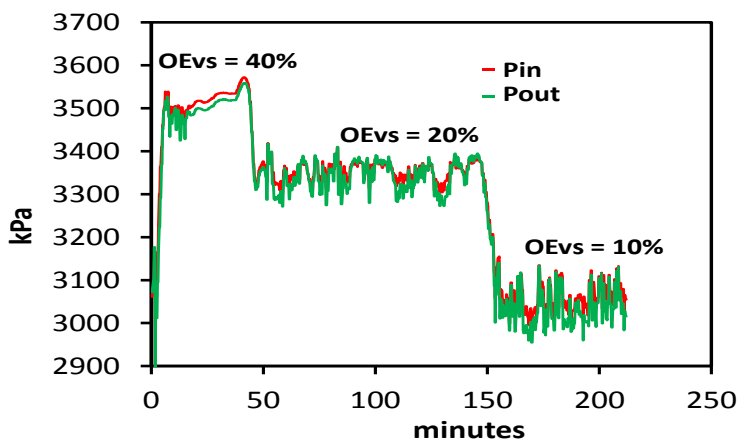

Figure 3. Inlet and outlet GHE pressure data

\section{Phase change process in the GHE}

The phase change process in the GHE was examined for the system working with different $\mathrm{CO}_{2}$ mass flow rates ( $\left.\dot{\mathrm{m}}_{\mathrm{CO}}\right)$ and two different number of active boreholes (two and three boreholes).

Figure 4 illustrates temperature profile for three different $\mathrm{CO}_{2}$ mass flow $\left(1.46 \times 10^{-3} \mathrm{~kg} / \mathrm{s}, 2.21 \times 10^{-3} \mathrm{~kg} / \mathrm{s}\right.$ and $\left.2.58 \times 10^{-3} \mathrm{~kg} / \mathrm{s}\right)$ per borehole in a system operating with four active boreholes. Table 4 gives the tests conditions and the main results. For each mass flow rate, two temperature profiles are presented: one at the shutdown-period (recovered ground) and the other one during operation. As mentioned previously, the shutdown-period profile (black dash lines) illustrates the ground temperature at the vicinity of the borehole before it has been disturbed by the experiment. As the tests were conducted in different days of the year, the shallow ground temperatures are not identical. The blue solid lines present $\mathrm{CO}_{2}$ temperature profile inside the borehole for a given mass flow rate. Arrows on the curves indicate the flow direction of $\mathrm{CO}_{2}$ inside the pipe. In each profile, two regions can be distinguished: (a) two-phase region and (b) single-phase region. In the former region, $\mathrm{CO}_{2}$ temperature remains constant due to the large amount of energy from the latent heat of vaporization, indicating that low pressure drop is maintained in the flow. The length of this region represents the length of complete evaporation, and it is equal to $10 \mathrm{~m}$ from the inlet of the first leg for case \#1. However, it is equal to $40 \mathrm{~m}$ for the two other cases.

A comparison of cases \#1 and \#2 shows that the length of the two-phase region inside the borehole increased with the higher flow rate associated with large refrigerant quantities inside the GHE. This trend is not specific to $\mathrm{CO}_{2}$ but general for all refrigerants. When comparing cases \#2 and \#3, however, the length of the two-phase region did not increase with higher flow rate (i.e, case \#3). On the other hand, $\mathrm{T}_{\text {evap }}$ decreased due to the phase change process, compensating for the increase in the evaporation length. This result confirms our previous expectation meaning that 
the phase change process depends on both $\mathrm{T}_{\text {evap }}$ and $\mathrm{CO}_{2}$ mass flow rate. Note that it was not possible to perform the tests with variable $\mathrm{T}_{\text {evap }}$ (without changing the mass flow rate) in order to highlight its effect on phase change process in the GHE.

The single-phase region starts from the last point of the two-phase region and finishes at the end of the second leg. The temperature variation of $\mathrm{CO}_{2}$ is more significant in case \#1 due to the relatively low specific heat of singlephase $\mathrm{CO}_{2}$. In this case, single-phase $\mathrm{CO}_{2}$ fills the major part of the GHE. The $\mathrm{CO}_{2}$ temperature increases from -2.5 ${ }^{\circ} \mathrm{C}$ to reach the UTG, which is the maximum temperature that can be reached, then, it decreases in the second leg due to the negative thermal interaction with the first leg as well as the cold soil temperature at the shallow depth. The borehole is less efficient in this case (case\#1). The superheating, observed for the case $\# 1$ is $1{ }^{\circ} \mathrm{C}$ higher than that of case \#2.

As it can be seen in table 4, the borehole extraction rate in case \#3 shows a slight difference compared to case \#2, while it is $43 \%$ higher than that of the case \#1 in which the major part of the GHE is filled by single-phase $\mathrm{CO}_{2}$. This means that a partial two-phase flow rather than a full two-phase flow regime along the U-tube length leads to lower borehole performance and it has to be avoided for more efficient DX-GSHP systems.

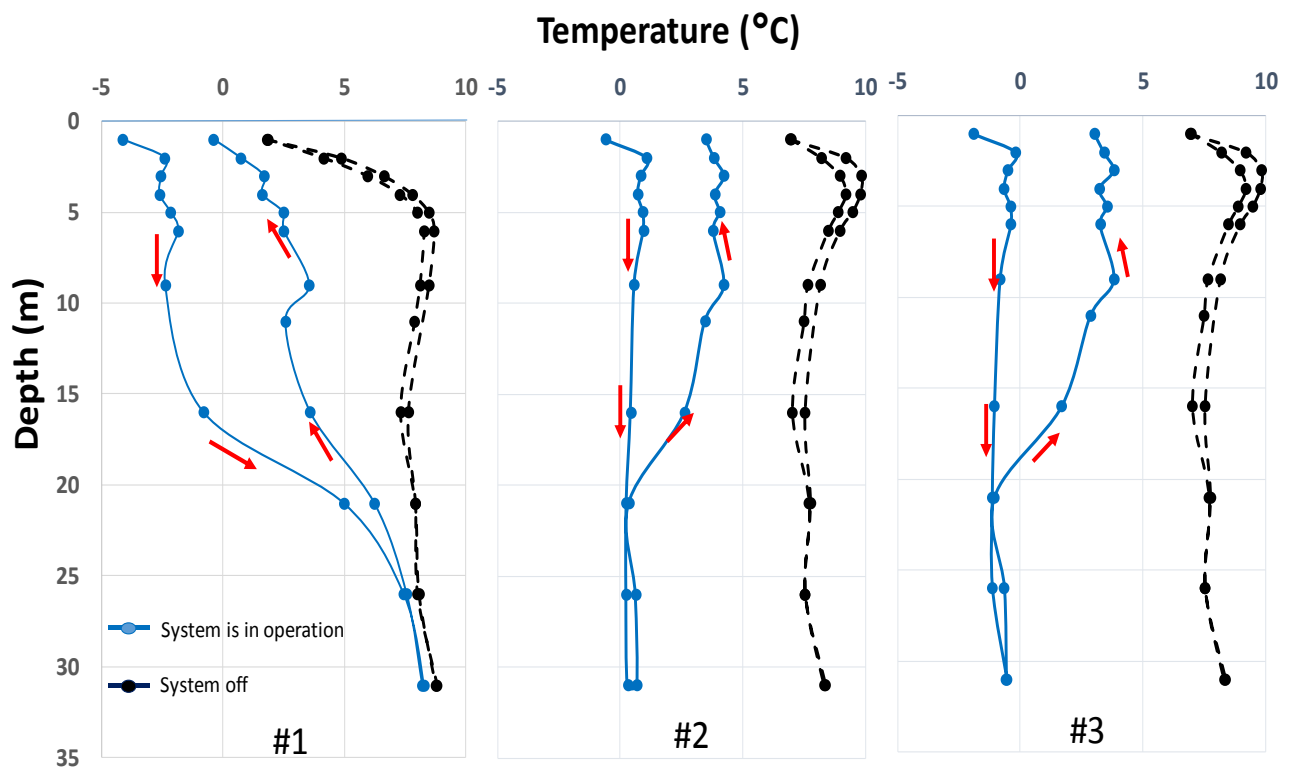

Figure 4. Pipe wall temperature variation along the borehole for different mass flow rates

Table 4. Tests conditions and results

\begin{tabular}{|c|c|c|c|c|c|c|c|c|}
\hline $\begin{array}{c}\text { Case } \\
\text { Number } \\
\end{array}$ & $\begin{array}{c}\text { Number } \\
\text { of } \\
\text { Boreholes }\end{array}$ & $\begin{array}{l}\text { Tw, in } \\
\left({ }^{\circ} \mathrm{C}\right)\end{array}$ & $\begin{array}{c}\mathrm{CO}_{2} \\
\text { Gas bypass } \\
\text { flow } \\
(\mathrm{kg} / \mathrm{s}) \times \mathbf{1 0}^{\mathbf{3}} \\
\end{array}$ & $\begin{array}{c}\mathrm{CO}_{2} \\
\text { total } \\
\text { liquid flow } \\
(\mathbf{k g} / \mathbf{s}) \times 10^{3} \\
\end{array}$ & $\begin{array}{c}\mathrm{CO}_{2} \\
\text { liquid flow } / \text { bor } \\
(\mathrm{kg} / \mathrm{s}) \times 10^{3}\end{array}$ & $\begin{array}{l}\mathrm{T}_{\text {evap }} \\
\left({ }^{\circ} \mathrm{C}\right)\end{array}$ & $\begin{array}{l}\text { Operation } \\
\text { period } \\
\text { (hours) }\end{array}$ & $\begin{array}{c}Q_{\mathrm{GHE} / \text { bor }} \\
(\mathrm{kW})\end{array}$ \\
\hline 1 & 4 & 35 & 11.90 & 5.86 & 1.46 & -2.55 & 15 & 0.3 \\
\hline 2 & 4 & 35 & 11.10 & 8.78 & 2.21 & 0.50 & 12 & 0.57 \\
\hline 3 & 4 & 30 & 7.53 & 10.33 & 2.58 & -1.2 & 2.5 & 0.59 \\
\hline
\end{tabular}

Figure $5 \mathrm{a}$ and $5 \mathrm{~b}$ presents the change of $\mathrm{CO}_{2}$ fluid temperature profile for two different number of active boreholes. The water mass flow rate to the gas cooler was set to $0.25 \mathrm{~kg} / \mathrm{s}$ during all the tests. Table 5 illustrates the main test conditions and results. Here again the solid lines show the pipe wall temperature profile representing the $\mathrm{CO}_{2}$ flow temperature along the U-tube in three cases. Black dash lines represent the ground temperature profile 
before starting the system. As shown in this figure, the temperature profiles show clearly the evaporation length, twophase region with constant temperature $\left(\mathrm{CO}_{2}\right.$ quality $\left.<1\right)$ and single-phase region.

Firstly, systems with three and two active boreholes show different $\mathrm{CO}_{2}$ fluid temperature variation (single and two phase regions) along the borehole and different length for complete evaporation. Since the system with two active boreholes carries through a lower $\mathrm{T}_{\text {evap }}\left(-2.55{ }^{\circ} \mathrm{C}\right)$, higher mass flow rate $\left(3.31 \times 10^{-3} \mathrm{~kg} / \mathrm{s}\right)$ of liquid $\mathrm{CO}_{2}$ per borehole, this creates a larger temperature difference between the $\mathrm{CO}_{2}$ and the ground. Consequently, it results in a longer length for complete evaporation $(50 \mathrm{~m})$ and higher $\mathrm{Q}_{\mathrm{GHE} / \mathrm{bor}}$ compared to the case with three active boreholes. It means that employing more boreholes decreases the heat extracted per unit borehole due to lower $\mathrm{CO}_{2}$ mass flow rate.

Secondly, in both profiles, the temperature increase in the single-phase region is marginal as the temperature of the surrounding material (grout) decreases due to the cold soil temperature at the shallow depth.

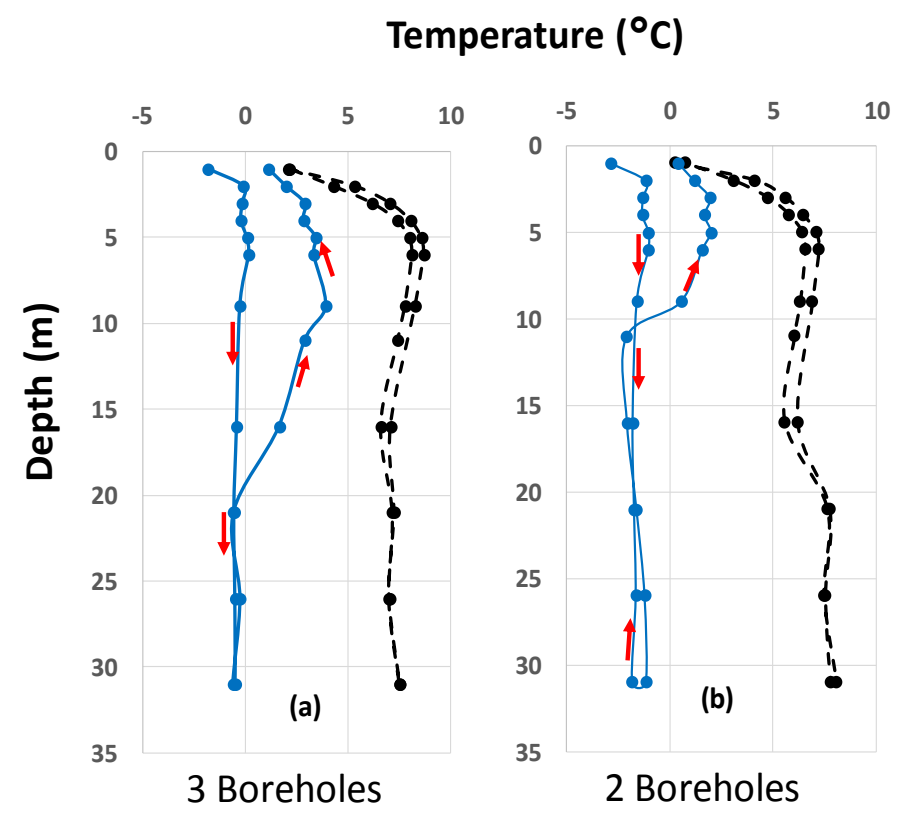

Figure 5. Pipe wall temperature variation for different number of active boreholes.

Table 5. Main test conditions and results

\begin{tabular}{|c|c|c|c|c|c|c|}
\hline $\begin{array}{c}\begin{array}{c}\text { Number } \\
\text { of } \\
\text { Boreholes }\end{array} \\
\end{array}$ & $\begin{array}{c}\mathrm{CO}_{2} \text { Gas bypass } \\
\text { flow } \\
(\mathrm{kg} / \mathrm{s}) \times 10^{3}\end{array}$ & $\begin{array}{l}\mathrm{CO}_{2} \text { total liquid flow } \\
(\mathrm{kg} / \mathrm{s}) \times 10^{3}\end{array}$ & $\begin{array}{c}\mathrm{CO}_{2} \\
\text { liquid flow/bor } \\
(\mathrm{kg} / \mathrm{s}) \times 10^{3}\end{array}$ & $\begin{array}{l}\mathrm{T}_{\text {evap }} \\
\left({ }^{\circ} \mathrm{C}\right)\end{array}$ & $\begin{array}{l}\text { Operation } \\
\text { period } \\
\text { (hours) }\end{array}$ & $\begin{array}{l}\mathrm{Q}_{\mathrm{GHE} / \text { bor }} \\
(\mathrm{kW})\end{array}$ \\
\hline$\overline{2}$ & $\begin{array}{l}10.40 \\
\end{array}$ & $\overline{c 6.61}$ & 3.31 & -2.55 & 15 & $\overline{c 0.66}$ \\
\hline 3 & 10.70 & 8.64 & 2.88 & -0.50 & 36 & 0.57 \\
\hline
\end{tabular}

\section{CONCLUSION}

In this work, an experimental investigation was performed to analyze the evaporartion process of $\mathrm{CO}_{2}$ in the GHE as well as its heat extraction performance for different $\mathrm{CO}_{2}$ mass flow rates per borehole and number of active boreholes of the system. For this purpose, pressure drop through the boreholes and the ground temperature profiles (before and after running the tests) were first monitored and analyzed.

Results show that the evaporation process was completed in the first leg of the U-tube with insufficient $\mathrm{CO}_{2}$ mass flow rate per borehole. Therefore, the single-phase $\mathrm{CO}_{2}$ fills the major part of the GHE. Furthermore, single- 
phase $\mathrm{CO}_{2}$ temperature at the first leg of the U-tube increases to reach the ground temperature in some cases and it decreases in the second leg due to the thermal interaction with the first leg as well as the cold soil temperature at the shallow depth. It is concluded that a partial two-phase flow rather than a full two-phase flow regime along the U-tube length leads to lower borehole heat extraction rate and it has to be avoided for more efficient DX-GSHP systems design.

It is also shown that employing more boreholes decreases the heat extracted per unit borehole due to lower $\mathrm{CO}_{2}$ mass flow rate. Nevertheless, increasing the number of GHEs over a certain limit may have a negative impact even on the system performance due to the borehole performance reduction as described in case with insufficient $\mathrm{CO}_{2}$ mass flow rate.

\section{ACKNOWLEDGMENTS}

This work was financially supported by the Energy Innovation Program (Natural Resources Canada).

\section{NOMENCLATURE}

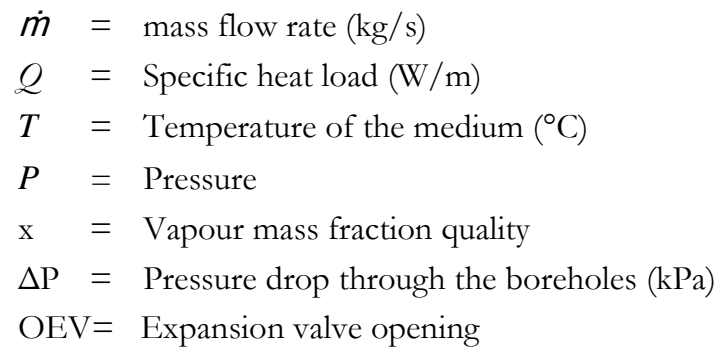

\section{Subscripts}

$$
\begin{aligned}
& \text { in }=\text { inlet } \\
& \text { out }=\text { outlet } \\
& \text { bor }=\text { Borehole } \\
& \text { evap }=\text { Evaporating } \\
& w=\text { Water }
\end{aligned}
$$

\section{REFERENCES}

Ghazizade-ahsaee, H. and M. Ameri. 2018. Energy and exergy investigation of a carbon dioxide direct-expansion geothermal heat pump. Applied Thermal Engineering 129: 165-178, doi:10.1016/j.applthermaleng.2017.10.022.

Yuefen, G., C. Yongzhao and S. Nan. Heat transfer performance of the underground CO2 pipe in the direct expansion ground source beat pump. Energy Procedia 2017, 105, 4955-4962, doi:10.1016/j.egypro.2017.03.989.

Mastrullo, R, A.W. Mauro, L. Menna and G.P. Vanoli. A model for a borehole heat exchanger working with CO2. Energy Procedia 2014, 45: 635-644, doi:10.1016/j.egypro.2014.01.068.

Austin, B.T. and K. Sumathy. 2011. Parametric study on the performance of a direct-expansion geothermal heat pump using carbon dioxide. Applied Thermal Engineering (31): 3774-3782.

Eslami-Nejad, P. M. Ouzzane and Z. Aidoun. 2014. Modeling of a two-phase $\mathrm{CO}_{2}$-filled vertical borehole for geothermal heat pump applications. Applied Energy (114): 611-620, doi:10.1016/j.apenergy.2013.10.028.

Eslami-Nejad, P., M. Badache, A. Bastani and Z. Aidoun. 2018. Detailed Theoretical Characterization of a Transcritical CO2 Direct Expansion Ground Source Heat Pump Water Heater. Energies. 11(2): 387. doi:10.3390/en11020387 
Beauchamp, B., L. Lamarche and S. Kajl. 2013. A numerical model of a U-tube vertical ground heat exchanger used as an evaporator. J. Energy Power Engineering (7): 237-249.

Rousseau, C., J.C. Fannou, L. Lamarche, M. Ouzzane and S. Kajl. 2015. Modeling and experimental validation of a transient direct expansion geothermal heat exchanger. Geothermics (57): 95-103.

Eslami-Nejad, P., M. Ouzzane and Z. Aidoun. 2015. A quasi-transient model of a transcritical carbon dioxide direct-expansion ground source beat pump for space and water beating. Applied Thermal Engineering (91): 259-269, doi:10.1016/j.applthermaleng.2015.07.058.

Guo, Y., G. Zhang, J. Zhou, J. Wu and W. Shen. 2012. A techno-economic comparison of a direct expansion ground-source and a secondary loop ground-coupled heat pump system for cooling in a residential building.

Applied Thermal Engineering (35): 29-39.

Wang, X.C. Ma, and Y. Lu. 2009. An experimental study of a direct expansion ground-coupled heat pump system in beating mode. Int. J. Energy Res., 33, 1367-1383.

Lenarduzzi, F.J. and T. J. Bennett. Direct-expansion ground-source heat pump with spiral ground coil. Heating

mode. ASHRAE Trans. 1991, 1991, 902-908.

Goulburn, J.R. and J. Fearon. 1978. Deep ground coil evaporators for heat pumps. Applied Energy 4(4): 293-313, doi:10.1016/0306-2619(78)90028-4

Mei, V.C.and V.D. Baxter. Experimental Analysis of Direct Expansion Ground Coupled Heat Pump Systems; Oak Ridge Natl. Lab.: Oak Ridge, TN, USA, 1991.

Yang, W. 2013. Experimental performance analysis of a direct-expansion ground source heat pump in Xiangtan, China. Energy (59): 334339, doi:10.1016/j.energy.2013.07.036.

Johnson, W.S. Field tests of two residential direct exchange geothermal heat pumps/Discussion. ASHRAE Trans. 2002, 108, 99.

Minea, V. Combined radiant floor and forced air heating with direct expansion GSHP in a northern greenbouse. In Proceedings of the 21st International Congress of Refrigeration, Washington, DC, USA, 17-22 August 2003.

Goulburn, J.R. and J. Fearon. 1983. Domestic heat pump with deep hole ground source evaporator. 2013. Applied Energy (14): 99-113.

Badache, M., M. Ouzzane, P. Eslami-Nejad, Z. Aidoun. 2018. Experimental study of a carbon dioxide direct-expansion ground source heat pump (CO2 DX-GSHP). Applied Thermal Engineering (130): 1480-1488 doi:10.1016/j.applthermaleng.2017.10.159. 